DOI: $10.17951 / \operatorname{lrp} .2019 .38 .3 .77-92$

\author{
ANNA Bochenek \\ Akademia Wychowania Fizycznego J. Piłsudskiego w Warszawie \\ Wydział Wychowania Fizycznego i Sportu w Białej Podlaskiej \\ ORCID - 0000-0002-7481-1936
}

Monika Drogosiewicz

Klinika Onkologii Instytut „Pomnik - Centrum Zdrowia Dziecka” w Warszawie

ORCID - 0000-0002-8193-5523

Katarzyna Sierpotowska

Zespół Szkół w Białej Podlaskiej

\title{
PRZYGOTOWANIE STUDENTÓW I NAUCZYCIELI WYCHOWANIA FIZYCZNEGO DO PRACY Z DZIEĆMI Z CHOROBĄ NOWOTWOROWĄ
}

\begin{abstract}
Streszczenie: Nauczyciel wychowania fizycznego we współczesnej szkole powinien posiadać szereg kompetencji do pracy z uczniem z chorobą przewlekłą, w tym z uczniem po zakończonej terapii przeciwnowotworowej. Rola aktywności fizycznej dla ozdrowieńców z choroby nowotworowej jest ogromna. Dlatego też uczeń ten nie powinien być zwalniany z uczestnictwa w szkolnym wychowaniu fizycznym, ale należy dołożyć wszelkich starań, aby aktywność fizyczna stała się elementem jego stylu życia do późnej starości. Celem badań jest diagnoza stanu przygotowania studentów i nauczycieli wychowania fizycznego do pracy z dzieckiem po zakończonym leczeniu przeciwnowotworowym. Grupę badanych stanowiło 172 nauczycieli wychowania fizycznego oraz 672 studentów kończących studia wychowania fizycznego. W badaniach posłużono się autorskim kwestionariuszem ankiety. Respondenci nie czują się przygotowani do pracy z dzieckiem po chorobie nowotworowej i niemal wszyscy chcieliby poszerzać swoją wiedzę w tym zakresie. Połowa badanych nie zna roli aktywności fizycznej w życiu ozdrowieńców, a około $30 \%$ nie wie, czy dzieci po zakończonej kuracji przeciwnowotworowej mogą uczestniczyć w wychowaniu fizycznym. Należy wprowadzić zmiany w procesie kształcenia nauczycieli wychowania fizycznego, aby przygotować ich do pracy z dzieckiem po chorobie nowotworowej. Należy stworzyć ofertę szkoleń podnoszących kompetencje nauczycieli wychowania fizycznego do pracy z dzieckiem z chorobą przewlekłą.
\end{abstract}

Słowa kluczowe: nauczyciel wychowania fizycznego, dziecko z chorobą nowotworową, wychowanie fizyczne 
Przygotowanie nauczycieli wychowania fizycznego do pracy z uczniem z chorobą przewlekłą staje się jednym z poważniejszych wyzwań współczesnego systemu oświatowego, zwłaszcza, że liczba dzieci chronicznie chorych stale rośnie (Małkowska-Szkutnik 2014, s. 90), a wychowanie fizyczne jest jednym z przedmiotów szkolnych skoncentrowanych wokół pomnażania zdrowia. Dotychczasowy system, w którym dzieci $\mathrm{z}$ niedostatkami zdrowotnymi zwalniane były z wychowania fizycznego zostaje wypierany na rzecz dostosowywania intensywności i formy aktywności do możliwości dziecka. Podkreślone zostało to w Rozporządzeniu Ministra Edukacji Narodowej z dnia 10 czerwca 2015 roku w sprawie szczegółowych warunków i sposobu oceniania, klasyfikowania i promowania uczniów i słuchaczy w szkołach publicznych, w którym znalazł sie zapis sugerujący, że dyrektor szkoły zwalnia ucznia z zajęć wychowania fizycznego wyłącznie na podstawie opinii o braku możliwości uczestniczenia w nich. Natomiast uczeń, który ma ograniczone możliwości wykonywania niektórych ćwiczeń powinien być zwolniony jedynie z tych ćwiczeń, a nie z wychowania fizycznego w ogóle (Dz.U. z 2015 r. poz. 843).

Niniejsze opracowanie stanowi fragment poszukiwań empirycznych, dotyczących uczestnictwa w różnych formach kultury fizycznej dzieci i młodzieży po zakończonym leczeniu choroby nowotworowej oraz uwarunkowań tego typu aktywności ${ }^{1}$. Temat podjęty został przede wszystkim z uwagi na to, że nowotwory stanowią jeden z poważniejszych problemów zdrowotnych tak w Polsce, jak i na całym świecie, a bieżące tendencje zachorowań i raporty Światowej Organizacji Zdrowia prognozują, że rak prawdopodobnie stanie się głównym powodem śmierci ludzi w XXI wieku (Meder 2014, s. 50). Każdego roku w krajach Unii Europejskiej rozpoznaje się 15 tys. nowych zachorowań wśród osób do 14. roku życia i 20 tys. u młodzieży i młodych dorosłych w wieku 15-24 lata (Szymborski, Didkowska, Wojciechowska 2014, s. 117; Kowalczyk 2011, s. 5). Jakkolwiek nowotwory wciąż pozostają pierwszą chorobową przyczyną śmierci w tej grupie wiekowej, to obecnie skuteczność ich leczenia u dzieci i młodzieży wzrosła na przestrzeni ostatnich 50 lat z 30\% do 70-80\% (Stenka, Izdebski 2017, s. 335). Oznacza to, że jest ona znacznie wyższa niż w populacji dorosłych pacjentów onkologicznych (Soares-Miranda i in. 2013, s. 106). Obecnie w Polsce jest około 10 tys. dzieci i młodzieży, których stan zdrowia jest stale monitorowany ze względu na to, że przeszli oni chorobę nowotworową, a wedle wszelkich przewidywań z każdym rokiem liczba ta będzie rosła (Kowalczyk 2011, s. 6).

W minionym dwudziestoleciu zwracano uwagę na aktywność fizyczną jako środek, który może zostać wykorzystany na różnych etapach choroby nowo-

${ }^{1}$ Praca naukowa finansowana ze środków budżetowych Ministerstwa Nauki i Szkolnictwa Wyższego na naukę w latach 2017-2018 jako projekt badawczy DS.251 Akademii Wychowania Fizycznego J. Piłsudskiego w Warszawie Wydział Wychowania Fizycznego i Sportu w Białej Podlaskiej 
tworowej (Vermaete i in. 2014, s. 411-424), podnosząc sprawność, odporność, zapobiegając pojawieniu się niektórych następstw leczenia oraz z dużym prawdopodobieństwem drugich nowotworów w dorosłym życiu (Litwiniuk, Kara 2012, s. 229-232; Soares-Miranda i in. 2017, s. 75-81). Jest wiele opracowań potwierdzających istnienie takiego związku w przypadku ludzi dorosłych (Bouillet $\mathrm{i}$ in. 2015, s. 76-78; Schmitz 2011, s. 189-216; Sellar, Courneya 2011, s. 237-254; Jones 2011, s. 255-274; Vermaete i in. 2014, s. 411-424; Fong 2012, s. 70; Culos-Reed i in. 2017, s. 1243-1245), najbardziej optymistyczne sugerują, że utrzymanie wysokiego poziomu sprawności i aktywności fizycznej może zmniejszyć ryzyko nawrotu choroby, a nawet zgonu z powodu choroby zasadniczej (Demark-Wahnefried i in. 2018, s. 64-89; Schmitz 2011, s. 195-199). Natomiast studiów tego typu wciąż jest niewiele. Obecne poszukiwania koncentrują się głównie wokół aktywności fizycznej ozdrowieńców z choroby nowotworowej wieku dziecięcego i sugerują, że jest ona w tej grupie znacznie niższa niż ich rówieśników, a także niższa w porównaniu z okresem sprzed choroby (Ness i in. 2015, s. 645; Ruble i in. 2016, s. 352-353; San Juan, Wolin, Lucia 2011, s. 327-330). Obserwuje się u nich również niższy poziom sprawności fizycznej (Pawłowska i in. 2010, s. 73-75; Chalcarz i in. 2008, s. 280-285), krążeniowo-oddechowej (Braam i in. 2016, s. 2259-2261), mniejszą masę mięśniową (Takken i in. 2009, s. 440-448) i występowanie zespołu męczliwości (Yeh 2011, s. 3-12).

Mówiąc o aktywności fizycznej w kontekście specyfiki choroby nowotworowej należy zauważyć, że w trakcie intensywnej terapii większość dzieci jest objętych nauczaniem indywidualnym i w zależności od możliwości, postępów leczenia czy samopoczucia uczestniczą one w procesie dydaktycznym szkoły przyszpitalnej (Deręgowska 2012, s. 287). Spadek aktywności fizycznej w tym okresie jest czymś naturalnym i wynika ze złej kondycji psychofizycznej, osłabienia wywołanego chorobą czy leczeniem oraz szeregu innych uwarunkowań medycznych i psychologicznych. Zauważono mniejsze zainteresowanie określonymi formami ruchu, a także wyraźny spadek zaangażowania w codzienne czynności ruchowe. Niestety po zakończonym leczeniu sytuacja poprawia się nieznacznie - u większości dzieci po kuracji odnotowano spadek motywacji do podejmowania aktywności fizycznej i spowodowany tym niski poziom sprawności fizycznej (Vermaete 2014, s. 421; Ness 2015, s. 645). Po powrocie do szkoły uczniowie ci borykają się z trudnościami typowymi dla dzieci przewlekle chorych: problemami w przystosowaniu psychospołecznym, kłopotami związanymi z kontaktami interpersonalnymi, poczuciem odmienności fizycznej i zaniżoną samooceną (Konieczna 2016, s. 236-242; Samardakiewicz 2011, s. 168). Z kolei ograniczenie ilości bodźców docierających do dziecka osłabia jego aktywność poznawczą (Antoszewska 2006, s. 33-36) i rodzi szereg trudności w zakresie osiągnięć szkolnych. Problem pogłębia postawa rodziców wykazujących 
tendencje do nadopiekuńczości w stosunku do dzieci, które pokonały chorobę nowotworową, nawet wtedy, gdy stają się one dorosłe (Samardakiewicz 2011, s. 166).

Kompetencje nauczyciela wychowania fizycznego do pracy z dzieckiem, które wraca do szkoły po leczeniu onkologicznym, nabierają nowego znaczenia z uwagi na to, że liczba dorosłych ozdrowieńców z choroby nowotworowej wieku dziecięcego stale będzie rosła, a około $75 \% \mathrm{z}$ nich będzie borykać się z różnego rodzaju problemami zdrowotnymi wynikającymi z samej choroby oraz zastosowanego leczenia (Dickermann 2009, s. 16-17). Bardzo ważna jest rola rodziców, wychowawców i nauczycieli, którzy rozumiejąc problemy będące następstwem choroby i leczenia, posiądą wiedzę niezbędną do minimalizowania tych niepożądanych konsekwencji. Duża część tych uczniów była zwalniana dotychczas z lekcji wychowania fizycznego, często nie uczestnicząc w nich w ogóle lub w najlepszym razie biorąc bierny udział. Zadaniem systemu oświatowego jest udzielenie dzieciom $\mathrm{z}$ chorobami przewlekłymi szeroko rozumianego wsparcia, w tym związanego z powrotem do szkoły po trudnej kuracji, jaką jest proces leczenia choroby nowotworowej (Deręgowska 2012, s. 285-287). Badania dowodzą, że osoby, które uczestniczyły w programach interwencyjnych mających na celu podniesienie poziomu aktywności fizycznej wykazywały po ich zakończeniu wiele pozytywnych efektów przede wszystkim w obrębie codziennej aktywności ruchowej, której poziom wyraźnie wzrastał również po zakończeniu eksperymentu (San Juan, Wolin, Lucia 2011, s. 336-338), ale także w obszarze percepcji siebie, samooceny, poczucia własnej skuteczności i jakości życia (Ruble i in. 2016, s. 355).

Przygotowanie nauczyciela wychowania fizycznego do pracy z dzieckiem $\mathrm{z}$ chorobą nowotworową powinno być zbudowane na fundamencie kompetencji merytorycznych i psychologiczno-pedagogicznych (Bochenek, Sadowski 2015, s. 32). Punktem wyjścia jest rzeczowa wiedza (lub umiejętność jej zdobycia) na temat specyfiki samej choroby oraz roli aktywności ruchowej w życiu ozdrowieńców. Nauczyciel powinien poznać przebieg choroby, sposoby leczenia oraz rokowania i zdiagnozować poziom sprawności fizycznej dziecka w celu określenia, na ile zostało ograniczone jego funkcjonowanie. W porozumieniu $\mathrm{z}$ rodzicami lub lekarzem należy ustalić, jaki rodzaj aktywności fizycznej jest dla dziecka wskazany i z których ćwiczeń trzeba ewentualnie w jego przypadku zrezygnować. Ważnym elementem kompetencji nauczyciela do pracy z dzieckiem $\mathrm{z}$ chorobą nowotworową jest umiejętność oceniania go oraz opracowywania indywidualnych programów i strategii pomocy w sytuacjach niepowodzeń szkolnych. Nauczyciel powinien mieć również przygotowany schemat postępowania w przypadku pogorszenia się samopoczucia ucznia bądź zaostrzenia objawów chorobowych.

Praca $\mathrm{z}$ byłym pacjentem onkologicznym w rzeczywistości wymaga od nauczyciela wychowania fizycznego przede wszystkim elementarnej wiedzy na 
temat roli aktywności fizycznej w chorobach nowotworowych oraz postępowania wyznaczonego zasadami wychowania. Indywidualizacja procesu edukacyjnego oraz dbałość o dobrą komunikację między wszystkimi uczestnikami procesu dydaktyczno-wychowawczego z całą pewnością mogą stanowić punkt wyjścia do współpracy z uczniem po leczeniu przeciwnowotworowym.

\section{METODOLOGICZNE PODSTAWY BADAŃ WŁASNYCH}

Celem pracy jest diagnoza stanu przygotowania studentów i nauczycieli wychowania fizycznego do pracy z dzieckiem po zakończonym leczeniu przeciwnowotworowym. Problematyka badawcza została sprecyzowana w postaci następujących pytań:

1. Czy badani nauczyciele pracowali kiedykolwiek z dziećmi z chorobą nowotworową i jak wyglądało uczestnictwo tych uczniów w lekcjach wychowania fizycznego?

2. Czy według badanych dziecko z chorobą nowotworową po zakończonej kuracji może uczestniczyć w lekcjach wychowania fizycznego?

3. Jaka jest, zdaniem respondentów, rola aktywności fizycznej ozdrowieńców $\mathrm{z}$ choroby nowotworowej wieku dziecięcego?

4. Czy zmienne takie jak staż pracy nauczycieli oraz średnia ocen studentów różnicują ich przygotowanie do pracy z dzieckiem po przebytej chorobie nowotworowej?

W badaniach posłużono się autorskim kwestionariuszem ankiety skonstruowanym na potrzeby analizowanych poszukiwań empirycznych. Ankieta była anonimowa i dobrowolna, a na przeprowadzenie badań uzyskano zgodę Komisji Etyki Badań Naukowych Akademii Wychowania Fizycznego J. Piłsudskiego w Warszawie.

W opracowaniu statystycznym posłużono się programem SPSS 14 dla Windows. Analizy dokonano przy użyciu testu chi-kwadrat i testu t-studenta, ponadto obliczono współczynnik korelacji $\mathrm{C}_{\mathrm{Kor}}$. Przy weryfikacji analiz użyto współczynnika istotności na poziomie $\alpha=0,05$, co pozwoliło uznać za istotne statystycznie zmienne przy $p<0,05$.

Badania przeprowadzono w 2017 roku wśród 172 nauczycieli wychowania fizycznego różnych typów szkół z województw mazowieckiego, lubelskiego i podkarpackiego oraz 672 studentów kończących studia stacjonarne wychowania fizycznego I i II stopnia. Wzięli w nich udział studenci następujących uczelni: Akademia Wychowania Fizycznego w Warszawie, Akademia Wychowania Fizycznego w Katowicach, Akademia Wychowania Fizycznego w Gdańsku, Uniwersytet Rzeszowski, Politechnika Opolska, Wydział Wychowania Fizycznego i Sportu w Białej Podlaskiej. 
Z punktu widzenia przygotowania respondentów do pracy z uczniem o specyficznych potrzebach edukacyjnych istotną zmienną może stanowić doświadczenie nauczycieli, któremu przyjrzano się w kontekście stażu pracy. Najliczniej reprezentowani byli nauczyciele ze stażem pracy od 16 do 25 lat (41,3\%), najmniejszą grupą byli nauczyciele pracujący nie więcej niż 5 lat $(12,2 \%)$. Biorąc pod uwagę liczebności grup, rozkłady odpowiedzi oraz wymogi statystyczne, w niniejszym opracowaniu dokonano podziału nauczycieli na dwie grupy pod względem stażu pracy: osoby pracujące 15 lat lub mniej oraz nauczyciele ze stażem pracy powyżej 15 lat. $\mathrm{W}$ przypadku studentów uznano, że badany element ich kompetencji zawodowych może być skorelowany z ich średnią ocen za ostatni semestr studiów. Z deklaracji ankietowanych studentów wynika, że zdecydowana większość z nich posiada średnią między 3,75 a 4,49 (78,3\%), najmniej liczną grupą byli studenci najlepsi - ze średnią równą lub większą niż 4,5 (7,7\%).

\section{WYNIKI}

Uczestnictwo w szkolnym wychowaniu fizycznym stanowi dla dużej liczby dzieci, a zwłaszcza dzieci z chorobami przewlekłymi, jedną z niewielu okazji do podejmowania przez nich aktywności fizycznej, dlatego ważne jest to, aby brały one w tych lekcjach czynny udział. Zapytano badanych nauczycieli, czy w swojej dotychczasowej pracy spotkali się z uczniem po chorobie nowotworowej, a także czy uczestniczył on w lekcjach WF.

Tabela 1. Doświadczenie badanych nauczycieli w pracy z dziećmi $\mathrm{z}$ chorobą nowotworową

\begin{tabular}{|l|c|c|}
\hline \multicolumn{1}{|c|}{ Kategorie odpowiedzi } & $\boldsymbol{N}$ & $\%$ \\
\hline Pracowałem/pracuję z dzieckiem chorym na nowotwór na lekcjach WF. & 17 & 9,9 \\
\hline $\begin{array}{l}\text { Pracowałem z dzieckiem chorym na nowotwór, ale nie ćwiczyło ono na } \\
\text { lekcjach WF. }\end{array}$ & 27 & 15,7 \\
\hline Nigdy nie pracowałem z dzieckiem chorym na nowotwór. & 128 & 74,4 \\
\hline Razem & 172 & 100,0 \\
\hline
\end{tabular}

Analiza wyników przeprowadzonych badań wskazuje, że zdecydowana większość ankietowanych nauczycieli nigdy nie spotkała się w swojej pracy z dzieckiem, które chorowało w przeszłości na nowotwór $(74,4 \%)$. Blisko 10,0\% badanych nauczycieli ma doświadczenia $\mathrm{w}$ pracy $\mathrm{z}$ byłymi pacjentami onkologicznymi i respondenci ci deklarują, że dzieci brały udział w lekcjach wychowania fizycznego. 
Natomiast 15,7\% nauczycieli przyznaje, że obecnie lub w przeszłości pracowali z uczniami, którzy przeszli chorobę nowotworową, ale mieli oni stałe zwolnienie z lekcji WF (tab.1).

Tabela 2. Opinia badanych na temat możliwości uczestnictwa dzieci po chorobie nowotworowej w szkolnym wychowaniu fizycznym

\begin{tabular}{|c|c|c|c|c|c|c|c|c|c|c|}
\hline \multirow{4}{*}{$\begin{array}{c}\text { Dziecko } \\
\text { z chorobą } \\
\text { nowotworową } \\
\text { po zakończonej } \\
\text { kuracji }\end{array}$} & \multirow{2}{*}{\multicolumn{4}{|c|}{$\begin{array}{c}\text { Nauczyciele }(N=172) \\
\text { staż pracy }\end{array}$}} & \multicolumn{6}{|c|}{ Studenci $(N=672)$} \\
\hline & & & & & \multicolumn{6}{|c|}{ średnia ocen } \\
\hline & \multicolumn{2}{|c|}{$\begin{array}{l}\leq 15 \text { lat } \\
N=70\end{array}$} & \multicolumn{2}{|c|}{$\begin{array}{l}>15 \text { lat } \\
N=102\end{array}$} & \multicolumn{2}{|c|}{$\leq 3,74$} & \multicolumn{2}{|c|}{$3,75-4,49$} & \multicolumn{2}{|c|}{$\geq 4,50$} \\
\hline & $N$ & $\%$ & $N$ & $\%$ & $N$ & $\%$ & $N$ & $\%$ & $N$ & $\%$ \\
\hline $\begin{array}{l}\text { Może ćwiczyć } \\
\text { na lekcjach WF }\end{array}$ & 47 & 67,1 & 65 & 63,7 & 65 & 69,1 & 394 & 74,9 & 41 & 78,8 \\
\hline $\begin{array}{l}\text { Nie może ćwi- } \\
\text { czyć na lekcjach } \\
\text { WF }\end{array}$ & 2 & 2,9 & 1 & 1,0 & 7 & 7,4 & 10 & 1,9 & 2 & 3,8 \\
\hline Nie wiem & 21 & 30,0 & 36 & 35,3 & 22 & 36,8 & 122 & 23,2 & 9 & 17,3 \\
\hline Razem & 70 & 100,0 & 102 & 100,0 & 94 & 100,0 & 526 & 100,0 & 52 & 100,0 \\
\hline \multicolumn{5}{|c|}{$\begin{array}{l}N=172 \text { wartość testu chi-kwadrat } 1,264 \text { n.i. } \\
\mathrm{df}=2\end{array}$} & \multicolumn{6}{|c|}{$\begin{array}{l}N=672 \text { wartość testu chi-kwadrat }=10,126 \\
\mathrm{df}=4 \mathrm{C}_{\text {Kor }}=0,15\end{array}$} \\
\hline
\end{tabular}

Ponad $60 \%$ nauczycieli wychowania fizycznego twierdzi, że dziecko po przebytej chorobie nowotworowej może ćwiczyć na lekcjach WF. Jedynie niewielkie odsetki badanych uważają, że jest to niemożliwe, ale ponad 30\% respondentów nie potrafi na to pytanie odpowiedzieć. Nie stwierdzono zależności istotnej statystycznie między odpowiedziami badanych nauczycieli na to pytanie i ich stażem pracy. Natomiast w przypadku studentów stwierdzono zależność istotą statystycznie między średnią ocen badanych a ich stanowiskiem wobec możliwości uczestnictwa dzieci po chorobie nowotworowej w szkolnym wychowaniu fizycznym. Studenci, którzy uzyskali najniższą średnią, najczęściej przyznawali, że nie wiedzą, czy uczestnictwo byłych pacjentów onkologicznych w tej formie aktywności jest możliwe. Badania wykazały, że przekonanie o możliwości uczestnictwa tych dzieci w lekcjach WF jest częstsze w grupie studentów, którzy lepiej się uczą. Wartość współczynnika korelacji sugeruje jednak, że siła związku między zmiennymi jest słaba (tab. 2). 
Tabela 3. Potrzeba podnoszenia przez badanych kompetencji do pracy z dzieckiem $\mathrm{z}$ chorobą przewlekłą

\begin{tabular}{|c|c|c|c|c|c|}
\hline \multirow{3}{*}{$\begin{array}{l}\text { Kategorie } \\
\text { odpowiedzi }\end{array}$} & \multirow{2}{*}{\multicolumn{2}{|c|}{$\begin{array}{c}\text { Nauczyciele } \\
\text { staż pracy }\end{array}$}} & \multicolumn{3}{|c|}{ Studenci } \\
\hline & & & \multicolumn{3}{|c|}{ średnia ocen } \\
\hline & $\leq 15$ lat & $>15$ lat & $<3,74$ & $3,75-4,49$ & $4,50-5,0$ \\
\hline Czuję taką potrzebę & 95,7 & 93,1 & 85,1 & 90,9 & 94,2 \\
\hline $\begin{array}{l}\text { Nie mam takiej } \\
\text { potrzeby }\end{array}$ & 4,3 & 6,9 & 14,9 & 9,1 & 5,8 \\
\hline Razem & 100,0 & 100,0 & 100,0 & 100,0 & 100,0 \\
\hline \multicolumn{3}{|c|}{$\begin{array}{l}N=172 \text { wartość testu chi-kwadrat }=0,478 \text { n.i. } \\
\text { df }=1\end{array}$} & \multicolumn{3}{|c|}{$\begin{array}{l}N=672 \text { wartość testu chi-kwadrat }=4,02 \text { n.i. } \\
\text { df }=2\end{array}$} \\
\hline
\end{tabular}

Do respondentów skierowano pytanie o to, czy czują potrzebę podnoszenia swoich kompetencji do pracy z dzieckiem z chorobą przewlekłą i z ich deklaracji wynika, że ponad $90 \%$ nauczycieli i podobny odsetek studentów wychowania fizycznego przyznaje, że chcieliby zdobywać wiedzę i umiejętności w tej dziedzinie. Nie stwierdzono zależności istotnej statystycznie między potrzebą podnoszenia kompetencji do pracy $\mathrm{z}$ dzieckiem chorym a stażem pracy w przypadku nauczycieli, ani średnią ocen w przypadku studentów (tab. 3).

Tabela 4. Samoocena przygotowania respondentów do pracy z dzieckiem $\mathrm{z}$ chorobą przewlekłą

\begin{tabular}{|c|c|c|c|c|c|c|}
\hline \multicolumn{4}{|c|}{ Nauczyciele } & \multicolumn{3}{|c|}{ Studenci } \\
\hline staż pracy & $\begin{array}{c}\text { średnia } \\
\text { arytmetyczna }\end{array}$ & $\begin{array}{c}\text { odchylenie } \\
\text { standardowe }\end{array}$ & $\begin{array}{c}\text { wartość } \\
\text { testu } t\end{array}$ & średnia ocen & $\begin{array}{c}\text { średnia } \\
\text { arytmetyczna }\end{array}$ & $\begin{array}{c}\text { wartość testu } \\
\text { chi-kwadrat }\end{array}$ \\
\hline$\leq 15$ lat & 2,64 & 0,948 & \multirow{3}{*}{$\begin{array}{c}3,908 \text { n.i. } \\
\mathrm{df}=170\end{array}$} & $<3,74$ & 2,18 & \multirow{3}{*}{$\begin{array}{c}12,077 \text { n.i. } \\
\text { df }=8\end{array}$} \\
\hline \multirow{2}{*}{$>15$ lat } & \multirow{2}{*}{3,11} & \multirow{2}{*}{0,612} & & $3,75-4,49$ & 2,36 & \\
\hline & & & & $4,50-5,0$ & 2,42 & \\
\hline
\end{tabular}

Badani dokonali oceny przygotowania do pracy z dzieckiem z chorobą przewlekłą poprzez określenie na pięciostopniowej skali własnych kompetencji w tym zakresie (1 oznaczał zupełny brak przygotowania, a 5 przygotowanie bardzo dobre). Analiza ich odpowiedzi pokazuje, że respondenci nie czują się dobrze przygotowani do pracy z dziećmi z chorobami przewlekłymi. Nauczyciele pracujący 15 lat lub mniej uzyskali średnią ocenę 2,64, a nauczyciele ze stażem pracy ponad 15 lat 3,11 . Nie stwierdzono jednak zależności istotnej statystycznie między samooceną przygotowania nauczycieli a ich stażem pracy. Studenci uzyskiwali wyniki nieco niższe niż nauczyciele i zauważono, że samoocena przygotowania studentów wzrastała w grupach osób, które miały lepsze wyniki w nauce, ale analiza statystyczna 
nie wykazała związku między średnią ocen a samooceną przygotowania badanych do pracy z dzieckiem przewlekle chorym (tab. 4).

Tabela 5. Rola aktywności fizycznej w życiu ozdrowieńców z choroby nowotworowej w opinii badanych

\begin{tabular}{|c|c|c|c|c|}
\hline \multirow[t]{2}{*}{ Kategorie odpowiedzi } & \multicolumn{2}{|c|}{$\begin{array}{l}\text { Nauczyciele } \\
\quad(N=172)\end{array}$} & \multicolumn{2}{|c|}{$\begin{array}{l}\text { Studenci } \\
(N=672)\end{array}$} \\
\hline & $N$ & $\%$ & $N$ & $\%$ \\
\hline Poprawa kondycji psychofizycznej & 17 & 9,9 & 68 & 10,1 \\
\hline Wspomaga powrót do zdrowia & 22 & 12,8 & 83 & 12,4 \\
\hline Wzmacnianie organizmu, układu odpornościowego & 19 & 11,0 & 81 & 12,1 \\
\hline $\begin{array}{l}\text { Poprawa funkcjonowania w kontaktach interpersonal- } \\
\text { nych }\end{array}$ & 17 & 9,9 & 23 & 3,4 \\
\hline Poprawa sprawności fizycznej & 18 & 10,5 & 77 & 11,5 \\
\hline Profilaktyka chorób & 2 & 1,2 & 10 & 1,5 \\
\hline Poprawa w zakresie obrazu własnej osoby & 3 & 1,7 & 13 & 1,9 \\
\hline Zmniejszenie męczliwości & 2 & 1,2 & & \\
\hline Forma rehabilitacji & 11 & 6,4 & 20 & 3,0 \\
\hline Zwiększenie wydolności & 6 & 3,5 & 9 & 1,3 \\
\hline Odbudowa masy mięśniowej, siły & 7 & 4,1 & 20 & 3,0 \\
\hline Zachęcanie do podejmowania aktywności fizycznej & - & - & 16 & 2,4 \\
\hline Lepsze funkcjonowanie w życiu codziennym & - & - & 25 & 3,7 \\
\hline Zaspokajanie potrzeby ruchu & - & - & 3 & 0,4 \\
\hline Inne & 5 & 2,9 & 8 & 1,2 \\
\hline Nie wiem & 95 & 55,2 & 372 & 48,4 \\
\hline
\end{tabular}

Aktywność fizyczna odgrywa bardzo ważną rolę w przypadku ozdrowieńców $z$ choroby nowotworowej, respondentom zadano więc na ten temat pytanie otwarte. Z ich wypowiedzi wynika, że 55,2\% nauczycieli oraz 48,4\% studentów wychowania fizycznego nie potrafi wskazać tych korzyści. Pozostali badani zauważają przede wszystkim, że aktywność fizyczna stanowi dla rekonwalescentów czynnik wspomagający ich powrót do zdrowia oraz wzmacniający organizm po wyczerpującej chorobie, podkreślając zwłaszcza rolę w odbudowywaniu układu odpornościowego. Około $10 \%$ badanych akcentuje znaczenie aktywności fizycznej we wzmacnianiu kondycji psychicznej i fizycznej, zwracają też uwagę na to, że ruch sprzyja podnoszeniu i odbudowywaniu sprawności fizycznej, masy mięśniowej oraz wydolności organizmu. Ankietowani nauczyciele i studenci sugerują, że w przypadku dzieci, które zakończyły leczenie z powodu choroby nowotworowej aktywność fizyczna może odgrywać istotną rolę w kształtowaniu samooceny, ponieważ wyższa sprawność buduje stabilniejszy obraz siebie i tym 
samym wpływa na lepsze funkcjonowanie w kontaktach interpersonalnych. Niewielkie odsetki respondentów zauważają, że aktywność fizyczna w przypadku tej grupy dzieci i młodzieży może być formą rehabilitacji, że może ona przyczyniać się do zmniejszenia męczliwości i stanowić profilaktykę innych chorób, na które narażeni są ozdrowieńcy $\mathrm{z}$ choroby nowotworowej (w tym nawrotom choroby). Wśród studentów znalazły się też osoby, które zauważyły, że aktywność fizyczna może przyczyniać się do lepszego funkcjonowania w życiu codziennym oraz stanowić zachętę i motywację do systematycznej aktywności ruchowej (tab. 5).

\section{DYSKUSJA}

Jednym z naczelnych zadań stojących przed współczesną szkołą jest edukacja zdrowotna. Zostało to bardzo mocno zaakcentowane w podstawie programowej, w której to również wskazano wychowanie fizyczne, jako przedmiot w tym zakresie wiodący. Tymczasem Raport Najwyższej Izby Kontroli w 2014 roku pokazał, że w wychowaniu fizycznym w polskich szkołach nie wykorzystano ani możliwości, aby przeciwdziałać niskiej frekwencji i zwalnianiu z zajęć wychowania fizycznego, ani szans na podniesienie rangi samego przedmiotu w szkole i środowisku (Zaleski-Ejgierd 2014, s. 39-40). Współczesne wychowanie fizyczne boryka się z licznymi trudnościami: $\mathrm{w}$ świadomości dzieci i rodziców pokutuje mit jakoby było ono przedmiotem mniej ważnym niż inne, a uczniowie z niedostatkami zdrowotnymi, czyli najbardziej potrzebujący ruchu, są z niego zwalniani.

Problem uczestnictwa dzieci z chorobami przewlekłymi w szkolnym wychowaniu fizycznym podejmowany jest stosunkowo rzadko i jak się okazuje - zdecydowanie za rzadko. Najczęściej eksplorowane obszary związane z edukacją ucznia chorego dotyczą funkcjonowania takiego ucznia w szkole (Małkowska-Szkutnik, Mazur 2011, s. 239), udzielania mu pierwszej pomocy przedmedycznej czy jego autopercepcji (Konieczna 2016, s. 236-242). W obszarze zainteresowań badaczy najczęściej pojawia się uczeń $\mathrm{z}$ astmą, cukrzycą czy padaczką, natomiast nie ma w Polsce poszukiwań empirycznych dotyczących pracy nauczyciela wychowania fizycznego z dzieckiem po zakończonym leczeniu choroby nowotworowej, co uzasadnione jest tym, że dzieci te stanowią niewielki odsetek wszystkich uczniów o specjalnych potrzebach edukacyjnych. Biorąc jednak pod uwagę, że zdecydowana ich większość wróci po zakończonym leczeniu do szkoły i powinni poczuć się w niej pełnoprawnymi uczniami, należy ten problem poddać szerszej eksploracji.

Beata Antoszewska (2006, s. 218-227), badając sytuację szkolną dziecka z chorobą nowotworową, podkreślała, że uczniowie ci chcą mieć kontakt z nauczycielami i potrzebują widzieć w nich nie tylko źródło wiedzy, ale również towarzysza 
swoich problemów. Tymczasem z badań własnych wynika, że jedynie około 25\% ankietowanych nauczycieli wychowania fizycznego pracowało dotychczas z uczniem po chorobie nowotworowej, ale zdecydowana większość respondentów uważa, że byliby do takiej gotowi i przyznają, że dzieci po zakończonym leczeniu onkologicznym mogą brać udział w ich lekcjach. Niestety mimo tej deklaracji bardzo słabo wypada samoocena przygotowania do podjęcia tego typu zadań zarówno w grupie nauczycieli, jak i studentów. Ponad połowa respondentów nie wie, jakie znaczenie ma aktywność fizyczna dla ozdrowieńców z choroby nowotworowej, duża część przyznaje, że nie są przygotowani do takiej pracy, a ponad $90 \%$ wszystkich badanych deklaruje, że odczuwa potrzebę poszerzenia swojej wiedzy w tym zakresie. Bardzo mały odsetek badanych wskazał aktywność ruchową jako formę rehabilitacji, a ten aspekt nauczyciele WF powinni przecież zauważać jako jeden $\mathrm{z}$ najbardziej oczywistych. Możliwości podejmowania wysiłku fizycznego w ramach lekcji WF dzieci z chorobami nowotworowymi stają się w świetle tych ustaleń mocno ograniczone. Dotyczy to nie tylko tej grupy uczniów, ale dzieci z chorobami przewlekłymi w ogóle - ich uczestnictwo w szkolnym wychowaniu fizycznym jest często niemożliwe ze względu na obawy nauczycieli i ich brak przekonania o tym, że gotowi są podjąć się tego typu zadań w sposób odpowiedzialny i kompetentny (Łukasik, Pollok-Waksmańska, Woś 2013, s. 525). Podobne wyniki uzyskał zespół prowadzący badania dotyczące postaw wobec dzieci i młodzieży z padaczką. Niemal wszyscy nauczyciele wychowania fizycznego, którzy brali w nich udział przyznawali, że uczniowie ci powinni uczestniczyć w ich lekcjach, ale mieli także świadomość konieczności poszerzania swojej wiedzy w tym zakresie, bowiem około $25 \% \mathrm{z}$ nich przyznało, że praca z uczniem z padaczką jest dla nich sytuacją stresującą (Małkowska-Szkutnik i in. 2017, s. 26). Potwierdzeniem braków w kompetencjach nauczycieli wychowania fizycznego w tym zakresie mogą być również wyniki badań uczestnictwa w wychowaniu fizycznym dzieci i młodzieży z mukowiscydozą, z których wynika, że największymi barierami tego procesu jest niedostateczne przygotowanie samych nauczycieli WF (Maksymowicz 2011, s. 272). Z kolei w opiniach dzieci przewlekle chorych oraz ich rodziców można znaleźć wypowiedzi sugerujące, że skłonności do rezygnowania z udziału w lekcjach WF wynikają głównie z obaw nauczycieli oraz niedostosowania tychże lekcji do możliwości dziecka chorego (Małkowska-Szkutnik 2014, s. 106).

Aktywność fizyczna jest istotnym czynnikiem kształtującym zdrowie człowieka, wartościową formą spędzania czasu wolnego i jak się okazuje jedną z najtańszych i najprostszych metod wspierania kondycji psychofizycznej osób chorych, których we współczesnym społeczeństwie należy spodziewać się coraz więcej z uwagi na tzw. przejście zdrowotne (Szukalski 2008, s. 90-92). Związane jest ono ze zmianą głównego czynnika śmiertelności z ostrych chorób zakaźnych na choroby chro- 
niczne, wywołane głównie stylem życia, w tym także nowotwory. Ruch okazuje się nie tylko istotnym elementem profilaktyki chorób cywilizacyjnych, ale też wspierającym leczenie i pomagającym radzić sobie z późnymi następstwami wielu schorzeń. Należy zauważyć jednak, że aktywność fizyczna jest uwarunkowana społecznie, a w Polsce odsetek dorosłych podejmujących tego rodzaju zachowania jest bardzo niski. Może to stanowić dodatkowy problem, bo z dużym prawdopodobieństwem będziemy mieli do czynienia $\mathrm{z}$ sytuacją, w której dziecko po chorobie nowotworowej wychowuje się w rodzinie nieposiadającej odpowiednich wzorów aktywności ruchowej, dlatego tym ważniejszy jest aspekt szkolnego wychowania fizycznego. Nauczyciele WF mają do odegrania ogromną rolę edukacyjną, ponieważ odpowiednio przygotowany i realizowany proces edukacyjny nie tylko pozwoli dziecku przekraczać granice wyznaczone chorobą, budować jego postrzeganie siebie, wiarę we własne możliwości, ale także prawdopodobnie może stać się czynnikiem zapobiegającym różnym niekorzystnym następstwom choroby. Kształtowanie świadomości i odpowiedzialności nauczycieli wychowania fizycznego za ten proces należy podejmować już na etapie kształcenia ich w szkole wyższej, kładąc nacisk na kompetencje studentów do pracy z dziećmi o specjalnych potrzebach edukacyjnych. Uczestnictwo w przypadku dzieci i młodzieży z chorobą nowotworową w szkolnym wychowaniu fizycznym powinno stać się elementem stylu życia, również jako forma rehabilitacji i eliminowania niekorzystnych czynników zapobiegająca nawrotom choroby w przyszłości.

\section{WNIOSKI}

Przepisy regulujące przygotowanie studentów do wykonywania zawodu nauczycielskiego zobowiązują szkoły wyższe do wyposażenia absolwentów w kompetencje do pracy z uczniami o specjalnych potrzebach edukacyjnych. Realizacja tego postulatu będzie wymagać jednak od uczelni kształcących na kierunku wychowanie fizyczne gruntownej weryfikacji programów kształcenia i wprowadzenia do nich przedmiotów oraz treści, które pomogą studentom w zrozumieniu istoty choroby nowotworowej, roli aktywności fizycznej dla ozdrowieńców z tej choroby oraz wyposażą ich w umiejętności dostosowania metod i form pracy do dzieci ze specjalnymi potrzebami edukacyjnymi.

Dziecko z chorobą przewlekłą, w tym uczeń po przebytej chorobie nowotworowej, ma prawo uczęszczać do ogólnodostępnych szkół, a jego edukacja powinna być prowadzona zgodnie $\mathrm{z}$ indywidualnymi potrzebami. Należy stworzyć ofertę szkoleniową dla nauczycieli wychowania fizycznego, która umożliwi im podnoszenie własnych kompetencji do pracy z dzieckiem chorym, a tym samym zwiększy 
szansę na uczestnictwo tych dzieci w szkolnym wychowaniu fizycznym i ograniczy ilość długoterminowych zwolnień z wychowania fizycznego.

Konieczne są dalsze poszukiwania empiryczne w obrębie sprawności i aktywności fizycznej dzieci i młodzieży w trakcie i po zakończonym leczeniu choroby nowotworowej, a także monitorowanie ich stanu zdrowia w analizowanym kontekście. Stworzą one szanse na opracowanie bezpiecznej i dostosowanej do potrzeb i możliwości pacjentów oferty aktywności ruchowej, a także na ustalenie ewentualnego związku między występowaniem późnych następstw leczenia a aktywnością ruchową.

\section{LITERATURA}

Antoszewska B., 2006, Dziecko z choroba nowotworowa - problemy psychopedagogiczne. Kraków, Oficyna Wydawnicza Impuls.

Bochenek A., Sadowski J., 2015, Kompetencje nauczyciela wychowania fizycznego do pracy z dzieckiem przewlekle chorym. W: A. Bochenek (red.), Nauczyciel wychowania fizycznego. Kształcenie, zawód i praca. Biała Podlaska, Wydawnictwo WWFiS, 25-41.

Bouillet T., Bigard X., Brami C., Chouahnia K., Copel L., Dauchy S., Delcambre C., Descotes M.J., Joly F., Lepeu G., Marre A., Scotte F., Spano J.P., Vanlemmens L., Zelek L., 2015, Role of physical activity and sport in oncology Scientific commission of the National Federation Sport and Cancer CAMI. „Critical Reviews in Oncolgy Hematology", 94, 74-86.

Bramm K.I., van Dijk-Lokkart E.M., Kaspers G.L., Takken T., Huisman J., Bierings M.B., Merks J.H.M., van de Heuvel-Eibrink M.M., van Dulmen-den-Broeder E., Veening M.A., 2016, Cardiorespiratory fitness and physical activity in children with cancer. „Support Care Cancer”, 24 (5), 2259-2268. DOI: 10.1007/s00520-015-2993-1.

Chalcarz W., Popierz N., Merkiel S., Chybicka A., 2008, Zmiany aktywności fizycznej młodzieży po przebytej chorobie nowotworowej. „Nowiny Lekarskie”, 77/4, 280-285.

Culos-Reed S.N., Leach H.J., Capozzi L.C., Easaw J., Eves N., Millet G.Y., 2017, Exercise preferences and association between fitness parameters, physical activity, and quality of life in high-grade glioma patients. „Support Care Cancer”, 25, 1237-1246. DOI: 101007/s00520-016-3516-4.

Demark-Wahnefried W., Schmitz K., Alfano C.M., Bail J.R., Goodwin P.J., Thomson C.A., Bradley D.W. i in., 2018, Weight management and physical activity throught the cancer care continuum. „CA Cancer Journal For Clinicians”, 68, 64-69.

Deręgowska J., 2012, Edukacja dzieci i młodzież z choroba nowotworowa jako czynnik wsparcia. „Studia Edukacyjne”, 21, 279-298.

Dickermann J.D., 2009, Odległe skutki leczenia nowotworu złośliwego w dzieciństwie. „Pediatria po Dyplomie”, 13, 16-32. 
Fong D.Y., Ho J.W., Hui B.P., Lee A.M., Macfarlane D.J., Leung S.S., Cerin E., Chan W.Y., Leung I.P., Lam S.H., Taylor A.J., Cheng K.K., 2012, Physical activity for cancer survivors: meta-analysis of randomised controlled trials. „British Medical Journal”, 344; e70. DOI: 10.1136/bmj.e.70.

Gotte M., Taraks S., Boos J., 2014, Sports in pediatric oncology: the role(s) of physical activity for children with cancer. „Pediatric Hematology Oncology”, 36, 2, 85-90.

Jones W.L., 2011, Physical activity and lung cancer survivorship. W: K.S. Courneya, Ch.M. Firedenreich (red.), Physical activity and cancer. Berlin, Springer, 255-274.

Konieczna I., 2016, Autopercepcja u dzieci z choroba przewlekła. „Forum Pedagogiczne", 1, 234-246.

Kowalczyk J. 2011, Epidemiologia nowotworów dziecięcych. W: J. Kowalczyk (red.), Wprowadzenie do onkologii i hematologii dziecięcej. Skrypt dla lekarzy specjalizujacych się w onkologii i hematologii dziecięcej. Warszawa, Wydawnictwo Centrum Medyczne Kształcenia Podyplomowego, 5-9.

Łukasik R., Pollok-Waksmańska W., Woś H., 2013, Problematyka funkcjonowania dziecka z choroba przewlekłą w szkole. „Problemy Pielęgniarstwa”, 21(3), 523-527.

Maksymowicz L., 2011, Rola nauczyciela wychowania fizycznego w rehabilitacji dziecka przewlekle chorego. W: S. Juszczyk, J. Ogrodnik, E. Przybyła (red.), Osobowość, kompetencje, powinności nauczyciela i wychowawcy. Katowice, Wydawnictwo AWF, 253-279.

Małkowska-Szkutnik A., 2014, Choroby przewlekłe u dzieci i młodzieży jako narastający problem społeczny. „Studia BAS”, 2(38), 89-112.

Małkowska-Szkutnik A., Mazur J., 2011, Funkcjonowanie w szkole uczniów z choroba przewlekła. „Problemy Higieny i Epidemiologii”, 92(2), 232-240.

Małkowska-Szkutnik A., Woynarowska B., Kleszczewska D., Salonna F., Vorlicek M., Gajewski J., 2017, Wiedza i przekonania nauczycieli w Polsce $i$ Czechach wobec uczniów z padaczka oraz przygotowanie nauczycieli do pracy z tymi uczniami. Raport $z$ badań. Warszawa, Epischool.

Meder J., 2014, Rak głównym zabójca ludzi w XXI wieku; Narodowy Program Zwalczania Chorób Nowotworowych. W: A. Potrykowska. Z. Strzelecki, J. Szymborski, J. Witkowski (red), Zachorowalność i umieralność na nowotwory a sytuacja demograficzna Polski. Warszawa, Rządowa Rada Ludności, 50-85.

Ness K., Mertens A., Hudson M.M., Wall M., Leisenring W.M., Oeffinger K.C., Sklar Ch.A., Robinson L.L., Gurney J.G., 2005, Limitations on physical performance and daily activities among long-term survivors of childhood cancer. „Annals of Internal Medicine", 143, 639-647

Pawłowska K., Malicka I., Sławska M., Woźniewski M., Chybicka A., Kałwak K., 2010, Sprawność fizyczna dzieci leczonych z powodu choroby nowotworowej. „Onkologia Polska", 13, 2, 71-76. 
Rozporzadzenie Ministra Edukacji Narodowej z dnia 10 czerwca 2015 roku w sprawie szczegółowych warunków i sposobu oceniania. Klasyfikowania i promowania uczniów i słuchaczy w szkołach publicznych (Dz.U. z 2015 r. poz. 843).

Ruble K., Scarvalone S., Galicchio L., Davis L., Wells D., 2016, Group physical activity intervention for childhood cancer survivors: a pilot study. „Journal of Physical Activity and Health", 13, 352-359. DOI: 10.1123/jpah.2015-0050

Samardakiewicz M., 2011, Psychoonkologiczne aspekty chorób nowotworowych u dzieci. W: J. Kowalczyk (red.), Wprowadzenie do onkologii i hematologii dziecięcej. Warszawa, Wydawnictwo Centrum Medyczne Kształcenia Podyplomowego, 163-169.

San Juan A., Wolin K., Lucia A., 2011, Physical activity and pediatric cancer survivorship. W: K.S. Courneya, Ch.M. Friedenreich (red.), Physical activity and cancer. Berlin, Springer, 319-348.

Schmitz K., 2011, Physical activity and breast cancer survivorship. W: K.S. Courneya, Ch.M. Firedenreich (red.), Physical activity and cancer. Berlin, Springer, 189-216. Sella C.M., Courneya K.S., 2011, Physical activity and gastrointestinal cancer survivorship. W: K.S. Courneya, Ch.M. Firedenreich (red.), Physical activity and cancer. Berlin, Springer, 237-254.

Soares-Miranda L., Fiuza-Luces C., Lassaletta A., Santa-Sosa E., Padilla J.R., FernandesCasanowa L., Lorenzo-Gonzalez R., Lopez-Mojares L., Perez M., Perez-Martinez A., Lucia A., 2013, Physical Activity in pediatric cancer patients with solid tumors (PAPEC): trial rationale and design. „Contemporary Clinical Trials”, 36, 106-115. DOI: 10.1016/j.cct2013.05.012.

Soares-Miranda L., Abreu S., Silva M., Peixoto A., Ramalho R., Correia da Silva P., Costa C., Teixeira J.P., Goncalves C., Moreira P., Mota J., Macedo G., 2017, Cancer survivor study (CASUS) on colorectal patients: longitudinal study on physical activity, fitness, nutrition, and its influences on quality of life, disease recurrence, and survival. Rationale and design. „International Journal of Colorectal Disease”, 32, 75-81. DOI: 10.1007./s00384-016-2671-x.

Stenka K.E., Izdebski P.K., 2017, Radzenie sobie przez dzieci i młodzież z doświadczeniem choroby nowotworowej oraz skutkami jej leczenia. „Psychiatra Psychologia Kliniczna", 17(4), 334-341.

Szukalski P., 2008, Ewolucja umieralności i niepełnosprawności w świetle koncepcji rektangularyzacji krzywej przeżycia. W: J.T. Kowaleski, P. Szukalski (red.), Starzenie się ludności Polski - między demografia a gerontologia społeczną. Łódź, Wydawnictwo Uniwersytetu Łódzkiego, 89-123.

Szymborski J., Didkowska J., Wojciechowska U., 2014, Nowotwory złośliwe u dzieci i młodzieży w Polsce. W: A. Potrykowska. Z. Strzelecki, J. Szymborski, J. Witkowski (red.), Zachorowalność i umieralność na nowotwory a sytuacja demograficzna Polski. Warszawa, Rządowa Rada Ludności, 117-146. 
Takken T., van der Torre P., Zwernik M., Hulzebos E.H., Bierings M., Helders P.J., van der Net P.J., 2009, Development, feasibility and efficacy of community-based exercise training program in pediatric cancer survivor. „Psychoonkology”, 18. 440-448.

Tomaszewska-Lampart I., Samardakiewicz M., 2013, Aktywność fizyczna u dzieci leczonych z powodu nowotworu. „Psychoonkologia”, 3, 113-118.

Vermaete N., Wolter P., Verhoef G., Gosselink R., 2014, Physical activity and physical fitness in lymphoma patients before, during, and after chemoterapy: a prospective longitudinal study. „Annals of Hematology”, 93, 411-424. DOI: 10.1007/s00277013-1881-3

Yeh C.H., Wai P.W., Lin U.S., Chung Y.P., 2011, A pilot study to examine the feasibility and effects of a home-based aerobic program on reducing fatigue in children with acute lymphoblastic leukemia. „Cancer Nursing”, 34(1), 3-12. DOI: 10.1097/ NCC.0b013e3181e4553c

Zaleski-Ejgierd A., 2014, Wychowanie fizyczne w szkołach. „Kontrola Państwowa”, $5,39-54$.

\title{
PREPARATION OF STUDENTS AND TEACHERS OF PHYSICAL EDUCATION TO WORK WITH CHILDREN WITH CANCER
}

\begin{abstract}
Introduction: A physical education teacher in a modern school should have many competences to work with a student with chronic illness, including a student after anticancer therapy. The role of physical activity for cancer survivors is enormous. Therefore, this student should not be released from participation in school physical education, but every effort should be made to make physical activity an element of his lifestyle until late old age. Material and methods: The aim of the research is to diagnose the level of preparation of students and teachers of physical education to work with children with cancer. The group of respondents was 172 physical education teachers and 672 students completing physical education studies. The research used the author's questionnaire. Results: Respondents do not feel prepared to work with a child after cancer and almost everyone wants to expand their knowledge in this area. Half of the respondents do not know what is the role of physical activity in the life of cancer survivors, about $30 \%$ do not know whether children after cancer treatment can participate in physical education. Conclusions: Changes should be introduced in the process of educating physical education teachers to prepare them for work with a child after cancer treatment. It is necessary to create an offer of trainings raising the competences of physical education teachers to work with children with chronic disease.
\end{abstract}

Keywords: physical education teacher, child with cancer, physical education 